\title{
PELATIHAN OPTIMALISASI SUMBER DAN BAHAN AJAR ONLINE SEBAGAI PENUNJANG PEMBELAJARAN BAGI ANAK ASUH PANTI ASUHAN ARRIDHO
}

\author{
Indah Purnamasari $^{1^{*}}$, Abdul Rahman Kadafi ${ }^{2}$, Ishak Kholil ${ }^{3}$, Tuslaela $^{4}$, Sri Rusiyati ${ }^{5}$ \\ $1,2,3,4,5$ Universitas Nusa Mandiri \\ *Korespondensi: indah.ihi@ nusamandiri.ac.id, abdul.alk@ nusamandiri.ac.id, \\ ishak.ihk@nusamandiri.ac.id, tuslaela.tll@nusamandiri.ac.id, sri.siq@nusamandiri.ac.id
}

\begin{abstract}
ABSTRAK. Sesuai dengan keputusan Menteri Pendidikan dan Kebudayaan Republik Indonesia terkait Surat Edaran Nomor 4 Tahun 2020 tentang Pelaksanaan Kebijakan Pendidikan dalam Masa Darurat Penyebaran Covid-19 dimana Proses Belajar dari Rumah dilaksanakan melalui pembelajaran daring / jarak jauh. Dalam pelaksanaannya proses pembelajaran secara daring memunculkan permasalahanpermasalahan baru diantaranya lokasi guru dan peserta didik yang terpisah saat melaksanakan pembelajaran membuat guru tidak bisa memantau secara langsung aktivitas mahasiswa selama proses pembelajaran dan sebagian dari peserta didik, mengalami kesulitan dalam mengakses, mendapatkan sumber dan media pembelajaran untuk menunjang pemahaman dari materi yang sedang dipelajari. Berbagai inisiatif dilakukan untuk memastikan kegiatan belajar tetap berlangsung meskipun tidak adanya sesi tatap muka langsung. Teknologi, lebih spesifiknya internet, ponsel pintar, dan laptop sekarang digunakan secara luas untuk mendukung pembelajaran jarak jauh. Begitupun permasalahan yang dirasakan Yayasan Ar Ridho dimana sebagian anak asuh Ar Ridho merasa kurang optimal dalam pembelajaran, belum bisa mengoptimalkan media dan bahan ajar online dan pemanfaatan media online yang kurang maksimal dalam mendukung pembelajaran. Dalam rangka memenuhi kebutuhan pemahaman para peserta tentang sumber belajar maka dirasa perlu adanya pelatihan Optimalisasi Sumber dan Bahan Ajar Online Sebagai Penunjang Pembelajaran Bagi Anak Asuh Panti Asuhan Ar Ridho yang mampu memberikan penjelasan dan pemahaman cara mendapatkan bahan ajar dengan memanfaatkan media online. Tujuan pelatihan ini diharapkan para peserta pelatihan yang terdiri dari para pelajar menjadi dapat menambah berbagai referensi sumber dan bahan ajar yang diperlukan serta memudahkannya dalam memahami materi pembelajaran dan memanfaatkannya dalam mendukung proses pembelajaran secara daring.
\end{abstract}

Kata kunci: Pelatihan; Online, Bahan Ajar, Ar Ridho

ABSTRACT. In accordance with the decision of the Minister of Education and Culture of the Republic of Indonesia regarding Circular Letter Number 4 of 2020 concerning the Implementation of Education Policies in the Emergency Period for the Spread of Covid-19 where the Learning from Home Process is carried out through online I distance learning. In its implementation, the online learning process raises new problems including the location of teachers and students being separated when carrying out learning, making teachers unable to directly monitor student activities during the learning process and some of the students have difficulty in accessing, obtaining learning resources and media. to support understanding of the material being studied. Various initiatives were

This work is licensed under a Creative Commons Attribution-NonCommercial-ShareAlike 4.0

International License. 
taken to ensure that learning activities continued even in the absence of face-to-face sessions. Technology, more specifically the internet, smartphones, and laptops are now widely used to support distance learning. In order to meet the needs of participants' understanding of learning resources, it is deemed necessary to have training on Optimizing Online Teaching Resources and Materials as Learning Support for Ar Ridho Orphanage Fosters who are able to provide explanations and understanding of how to get learning resources by utilizing online media. The purpose of this training is that it is hoped that the training participants consisting of students will be able to add various reference sources and teaching materials needed and make it easier for them to understand learning materials and use them to support the online learning process.

Keywords: Training; Online, Teaching Materials, Ar Ridho

\section{PENDAHULUAN}

Wabah corona virus disease 2019 (Covid-19) yang telah melanda 215 negara didunia, memberikan tantangan tersendiri bagi lembaga Pendidikan[1]. Maka lembaga Pendidikan mengharuskan menjalankan proses kegiatan pembelajaran secara jarak jauh, yakni siswa belajar dan guru mengajar harus tetap berjalan meskipun peserta didik berada di rumah. Akibatnya, pendidik dituntut mendesain pembelajaran dengan memanfaatkan media daring (online). Hal Ini dilakukan sebagai upaya mengurangi interaksi banyak orang yang dapat memberi akses pada penyebaran virus corona[2]. Sesuai dengan keputusan Menteri Pendidikan dan Kebudayaan Republik Indonesia terkait Surat Edaran Nomor 4 Tahun 2020 tentang Pelaksanaan Kebijakan Pendidikan dalam Masa Darurat Penyebaran Covid-19[3]. Berbagai inisiatif dilakukan untuk memastikan kegiatan belajar tetap berlangsung meskipun tidak adanya sesi tatap muka langsung. Teknologi, lebih spesifiknya internet, ponsel pintar, dan laptop sekarang digunakan secara luas untuk mendukung pembelajaran jarak jauh[4]. Pada pembelajaran daring dapat menggunakan video, blog. Audio[5].

Kebijakan pembatasan interaksi dan kerumuman menyebabkan guru dan peserta didik diwajibkan untuk beradaptasi dengan situasi dan kondisi pandemi dan melakukan proses pembelajaran dengan yang berbeda dari kebiasaan yaitu dengan sistem tatap muka secara tidak langsung atau proses pembelajaran daring (dalam jaringan)[6]. Pandemic Covid-19 yang saat ini masih berlangsung, menjadikan aktivitas pembelajaran belum dapat dilaksanakan secara optimal tatap muka di sekolah. Pembelajaran dilaksanakan secara daring. Sebagian dari peserta didik, mengalami kesulitan dalam mengakses dan mendapatkan sumber dan media pembelajaran untuk menunjang pemahaman dari materi yang sedang dipelajari.

Pembelajaran yang dilaksanakan secara online juga memiliki tantangan tersendiri. Lokasi guru dan peserta didik yang terpisah saat melaksanakan pembelajaran membuat guru tidak bisa memantau secara langsung aktivitas mahasiswa selama proses pembelajaran. Tidak ada jaminan bahwa peserta didik benarbenar memperhatikan penjelasan yang diberikan oleh guru[1]. Dalam pembelajaran di tengah terjadinya wabah covid-19 peran teknologi sangatlah dibutuhkan, seperti yang telah dikatakan[7].

Yayasan Panti Sosial Asuhan Anak AR-RIDHO beralamat di Jl. Caringin No. 13 Kp. Kekupu, Rangkapan Jaya, Pancoran Mas, Kota Depok merupakan sebuah yayasan yang bergerak dalam bidang Pemberdayaan Masyarakat Menuju Masyarakat yang bernilai Islami. Dalam program pemberdayaan masyarakat, Ar Ridho mengembangakan program dalam bidang Sosial Dakwah dan fokus pada upaya pemberdayaan ummat terutama kaum dhuafa dan anak-anak yatim melalui Dana Sosial Masyarakat. Tahun 1982 bertepatan pada tanggal 8 Desember (12 Rabiul Awal) peletakan batu pertama yayasan Ar-

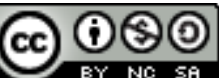

This work is licensed under a Creative Commons Attribution-NonCommercial-ShareAlike 4.0

International License. 
TRIDHARMADIMAS: Jurnal Pengabdian Kepada Masyarakat Jayakarta

http://journal.stmikjayakarta.ac.id/index.php/tridharmadimas

EmaiL: info@stmik.jayakarta.ac.id , tridharmadimas.jayakarta@gmail.com

DOI : 10.52362/tridharmadimas.v1i2.627/halaman : 68-76

E-ISSN: 2798-8295 (Online), P-ISSN: 2798-8554 (Print) Vol. 1, No.2, Desember 2021

Ridho. Pada tahun 1995 yayasan ini mulai dapat menampung anak-anak sekitar depok. Seiring berjalannya waktu, saat ini yayasan sudah memiliki tanah seluas + $1500 \mathrm{M} 2$ dan memiliki tiga bangunan asrama..

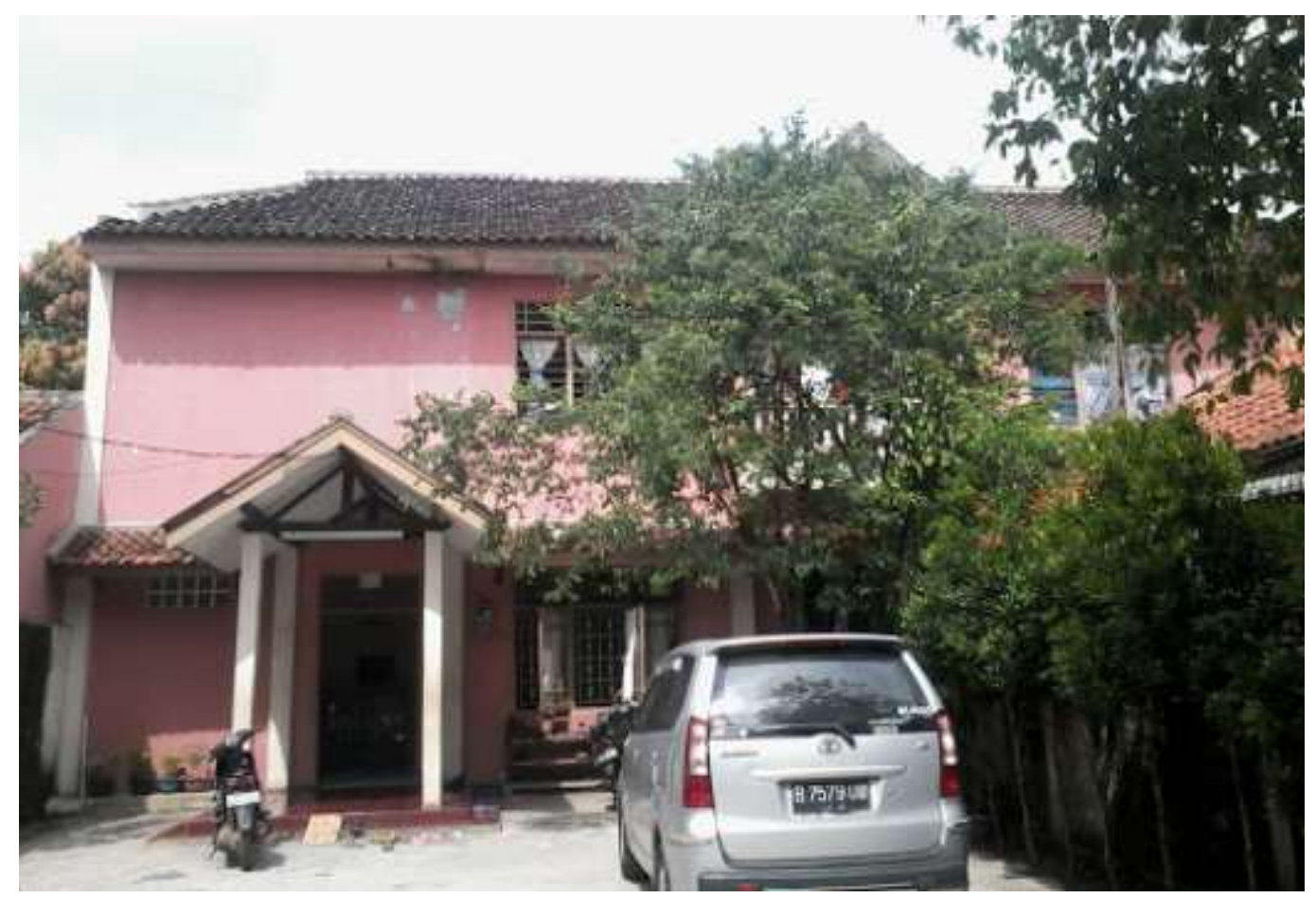

Gambar 1. Gedung Yayasan Ar Ridho Depok

Yayasan Ar Ridho yang menaungi anak-anak yatim dan dhuafa maksimal sebanyak 50 anak asuh dalam masa sekolah juga merasakan keresahan terhadap anak-anak didik nya. Permasalahan-permasalahan pembelajaran secara daring tersebut yang kita hadapi saat ini selama masa pandemi Covid-19 menuntut semua pihak untuk lebih cepat dan aktif untuk mengatasinya. Pembelajaran di masa pandemic saat ini dilakukan secara Online/Daring dengan memanfaatkan media online untuk belajar, begitupun bagi anakanak yatim piatu dan dhuafa yayasan Yayasan Panti Sosial Ar Ridho Depok menggunakan media online untuk belajar.

Ada beberapa masalah yang dihadapi Yayasan Ar Ridho sebagai Mitra kegiatan pengabdian masyarakat diantaranya:

a. Sebagian anak asuh Ar Ridho merasa kurang optimal dalam pembelajaran

b. Sebagian anak asuh Ar Ridho belum bias mengoptimalkan media dan bahan ajar online

c. Pemanfaatan media online yang kurang maksimal dalam mendukung pembelajaran.

Berdasarkan permasalahan-permasalahan tersebut, untuk memenuhi kebutuhan pemahaman para peserta tentang sumber belajar maka diperlukan adanya pelatihan yang mampu memberikan penjelasan dan pemahaman cara mendapatkan sumber belajar dengan memanfaatkan media online, sehingga diharapkan

This work is licensed under a Creative Commons Attribution-NonCommercial-ShareAlike 4.0 International License. 
para peserta pelatihan yang terdiri dari para pelajar tetap dapat memahami materi pembelajaran dan memanfaatkannya dalam mendukung proses pembelajaran secara daring. Media dan sumber belajar online banyak tersedia di internet, namun tidak sedikit dari para pelajar yang belum mampu mengoptimalisasi sumber belajar yang ada. Oleh karena itu, tim kami mengajukan kegiatan pengabdian masyarakat berupa Pelatihan Optimalisasi Sumber dan Bahan Ajar Online Sebagai Penunjang Pembelajaran bagi anak asuh Panti Asuhan Ar Ridho.

Solusi permasalahan yang ditawarkan dari identifikasi masalah yang dihadapi oleh mitra tersebut dapat disajkan dalam bentuk tabel solusi.

Tabel 1. Solusi Permasalahan

\begin{tabular}{|l|l|l|}
\hline \multicolumn{1}{|c|}{ Permasalahan } & \multicolumn{1}{|c|}{ Solusi } & \multicolumn{1}{c|}{ Keterangan } \\
\hline $\begin{array}{l}\text { Sebagian anak asuh Ar Ridho } \\
\text { merasa kurang optimal dalam } \\
\text { pembelajaran }\end{array}$ & $\begin{array}{l}\text { Pelatihan tentang bagaimana } \\
\text { mencari dan mendapatkan } \\
\text { media dan bahan ajar online }\end{array}$ & $\begin{array}{l}\text { Dapat mengetahui cara } \\
\text { mencari dan mendapatkan } \\
\text { media dan bahan ajar online }\end{array}$ \\
\hline $\begin{array}{l}\text { Sebagian anak asuh Ar Ridho } \\
\text { belum bisa mengoptimalkan } \\
\text { media dan bahan ajar online }\end{array}$ & $\begin{array}{l}\text { Pelatihan tentang } \\
\text { optimalisasi media dan bahan } \\
\text { ajar online }\end{array}$ & $\begin{array}{l}\text { Dapat mengoptimalisasi } \\
\text { media dan bahan ajar online } \\
\text { dalam meningkatkan } \\
\text { pemahaman materi ajar }\end{array}$ \\
\hline $\begin{array}{l}\text { Pemanfaatan media online } \\
\text { yang kurang maksimal dalam } \\
\text { mendukung pembelajaran }\end{array}$ & $\begin{array}{l}\text { Memberikan wawasan } \\
\text { berkaitan dengan tips dan trik } \\
\text { mendapatkan dan } \\
\text { memanfaatkan media online } \\
\text { dalam mendukung } \\
\text { pembelajaran }\end{array}$ & $\begin{array}{l}\text { Mengetahui cara dan } \\
\text { langkah-langkah untuk } \\
\text { mencari dan memanfaatkan } \\
\text { media online dalam } \\
\text { mendukung pembelajaran }\end{array}$ \\
\hline
\end{tabular}

\section{METODE}

Dengan mempertimbangkan masa pandemi saat ini, pelaksanaan pengabdian masyarakat di panti asuhan Ar-Ridho Depok secara online. Dengan peserta adalah anak didik pada panti asuhan ArRidho. Metode tahapan pelaksanaan pengabdian masyarakat tentang "Pelatihan Optimalisasi Sumber dan Bahan Ajar Online Sebagai Penunjang Pembelajaran bagi anak asuh Ar Ridho" terdiri dari 5 tahap yaitu:

1. Pengumpulan Data Mitra

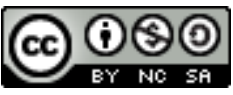

This work is licensed under a Creative Commons Attribution-NonCommercial-ShareAlike 4.0 International License. 
Pada tahap ini, dilaksanakan beberapa aktivitas dalam rangka mendapatkan informasi pendukung tentang mitra, meliputi pemetaan permasalahan mitra, diskusi dengan mitra untuk menentukan materi yang akan diberikan dan teknis pelaksanaan.

2. Pengajuan Proposal kegiatan Pengabdian Masyarakat kepada LPPM

Setelah didapatkan pemetaan masalah dan kebutuhan pengabdian masyarakat, tahapan berikutnya adalah penyusunan proposal berisi Pendahuluan, Target dan Luaran, Metode Pengabdian Masyarakat serta Biaya dan Jadwal Kegiatan.

3. Pelaksanaan Pelatihan

Pelaksanaan pelatihan dalam rangka pengabdian masyarakat ini dilakukan secara online dalam bentuk ceramah disampaikan oleh Tutor, diskusi atau tanya jawab dan praktikum dilakukan oleh para peserta memperhatikan dan mempraktekan penjelasan dibantu tim tutor.

4. Evaluasi

Utnuk mendapatkan masukan terhadap kegiatan guna perbaikan atas kekurangan atau kesalahan yang terjadi, maka setelah pelaksanaan pengabdian masyarakat tahap berikutnya adalah evaluasi dengan cara menyebarkan kuesioner kepada peserta pelatihan. Hal ini guna meningkatkan kualitas pengabdian masyarakat yang dilakukan di masa mendatang.

5. Hasil kegiatan

Luaran dari pelaksanaan pengabdian masyarakat berupa Laporan Pengabdian Masyarakat kepada LPPM dan Press Release pada media elektronik dengan harapan menginspirasi masyarakat luas tentang pemikiran konseptual atau ide-ide yang telah dicapai di bidang pengabdian masyarakat.

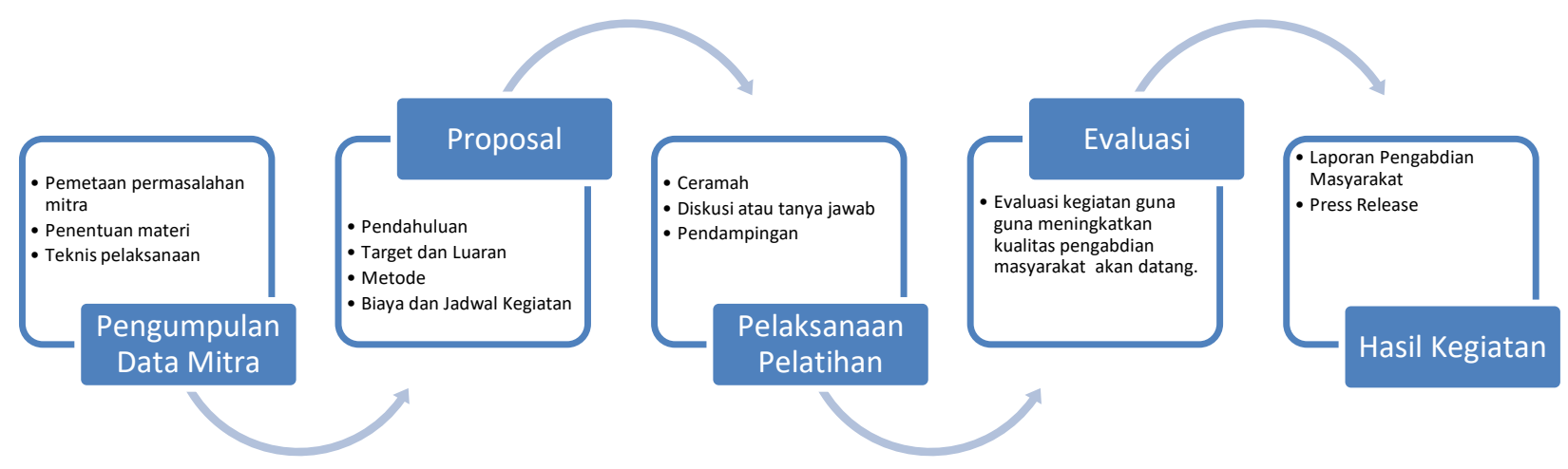

Gambar 2. Metode Tahapan Pengabdian Masyarakat

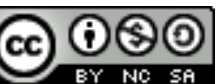

This work is licensed under a Creative Commons Attribution-NonCommercial-ShareAlike 4.0 International License. 


\section{HASIL DAN PEMBAHASAN}

Kegiatan pengabdian kepada masyarakat dengan tema "Pelatihan Optimalisasi Sumber dan Bahan Ajar Online Sebagai Penunjang Pembelajaran bagi anak asuh Panti Asuhan Ar Ridho" disajikan dalam bentuk ceramah, diskusi dan pelatihan secara online. Fasilitas yang diberikan kepada peserta selama pelatihan berlangsung yaitu berupa modul dan seperangkat alat penunjang visual untuk pemberian materi secara online seperti infocus, laptop, kamera dan sebagainya.

Kegiatan pengabdian kepada masyarakat ini diselenggarakan pada hari Minggu, 26 September 2021 pukul 09.00-12.00 WIB secara online dengan Zoom Meeting dimana untuk panitia dan peserta berada dalam satu ruang pelatihan di Yayasan Ar Ridho dengan mematuhi protokol kesehatan yang berlaku di masa pandemi ini.

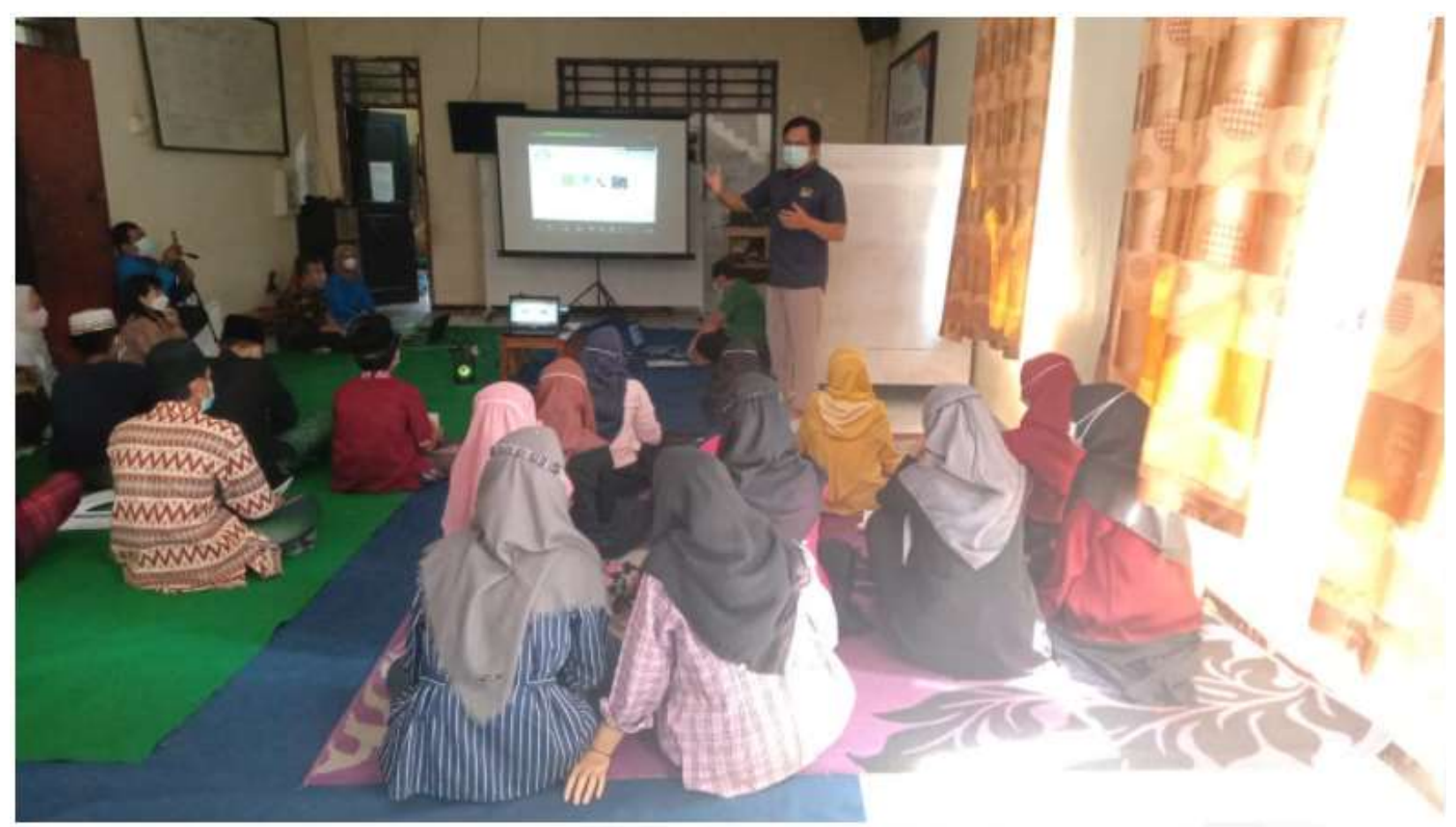

Gambar 3. Ruang dan Alat yang digunakan untuk Pelatihan

Peserta dalam kegiatan Pengabdian Masyarakat ini adalah anak-anak asuh yayasan Ar Ridho kota Depok yang berjumlah sekitar 20 anak usia sekolah. Dalam pelaksanaannya, pelatihan diawali dengan pembukaan kegiatan. Kemudian dilanjutkan pemateri memberikan pemaparan tentang teknologi informasi yang banyak dimanfaatkan untuk pembelajaran online seperti whatsapp, sms, telpon dan aplikasi lainnya.

This work is licensed under a Creative Commons Attribution-NonCommercial-ShareAlike 4.0 International License. 
TRIDHARMADIMAS: Jurnal Pengabdian Kepada Masyarakat Jayakarta

http://journal.stmikjayakarta.ac.id/index.php/tridharmadimas

EmaiL: info@stmik.jayakarta.ac.id , tridharmadimas.jayakarta@gmail.com

DOI : 10.52362/tridharmadimas.v1i2.627/halaman : 68-76

E-ISSN: 2798-8295 (Online), P-ISSN: 2798-8554 (Print) Vol. 1, No.2, Desember 2021

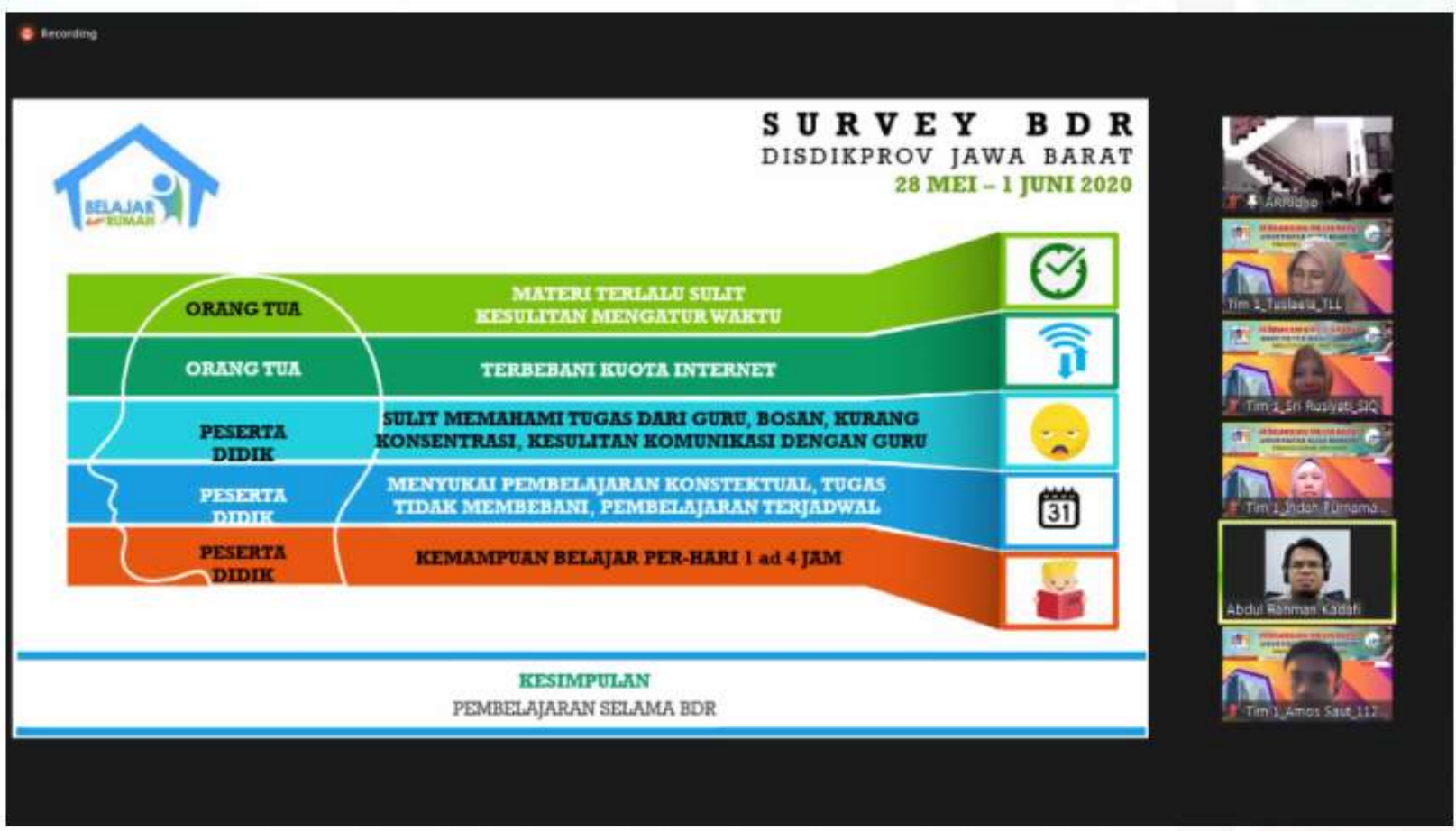

Gambar 4. Tutor memberikan penjelasan secara Online

Selanjutnya pemateri membahas tentang kesulitan-kesulitan yang dirasakan selama pembelajaran online kemudian memberikan penjelasan cara mendapatkan sumber belajar dengan memanfaatkan media online yang banyak tersedia di internet, sehingga para peserta pelatihan yang terdiri dari para pelajar dapat memanfaatkannya untuk mendukung proses pembelajaran secara daring.

Selama pelatihan berlangsung, peserta dapat langsung bertanya kepada pemateri apabila ada yang kurang dimengerti sehingga konten yang disampaikan dapat dipahami para peserta dengan baik. Pemateri juga memberikan game-game edukatif agar peserta aktif dan semangat dalam pelatihan.

This work is licensed under a Creative Commons Attribution-NonCommercial-ShareAlike 4.0

International License. 
TRIDHARMADIMAS: Jurnal Pengabdian Kepada Masyarakat Jayakarta

http://journal.stmikjayakarta.ac.id/index.php/tridharmadimas

EmaiL: info@stmik.jayakarta.ac.id , tridharmadimas.jayakarta@gmail.com

DOI : 10.52362/tridharmadimas.v1i2.627/halaman : 68-76

E-ISSN: 2798-8295 (Online), P-ISSN: 2798-8554 (Print) Vol. 1, No.2, Desember 2021

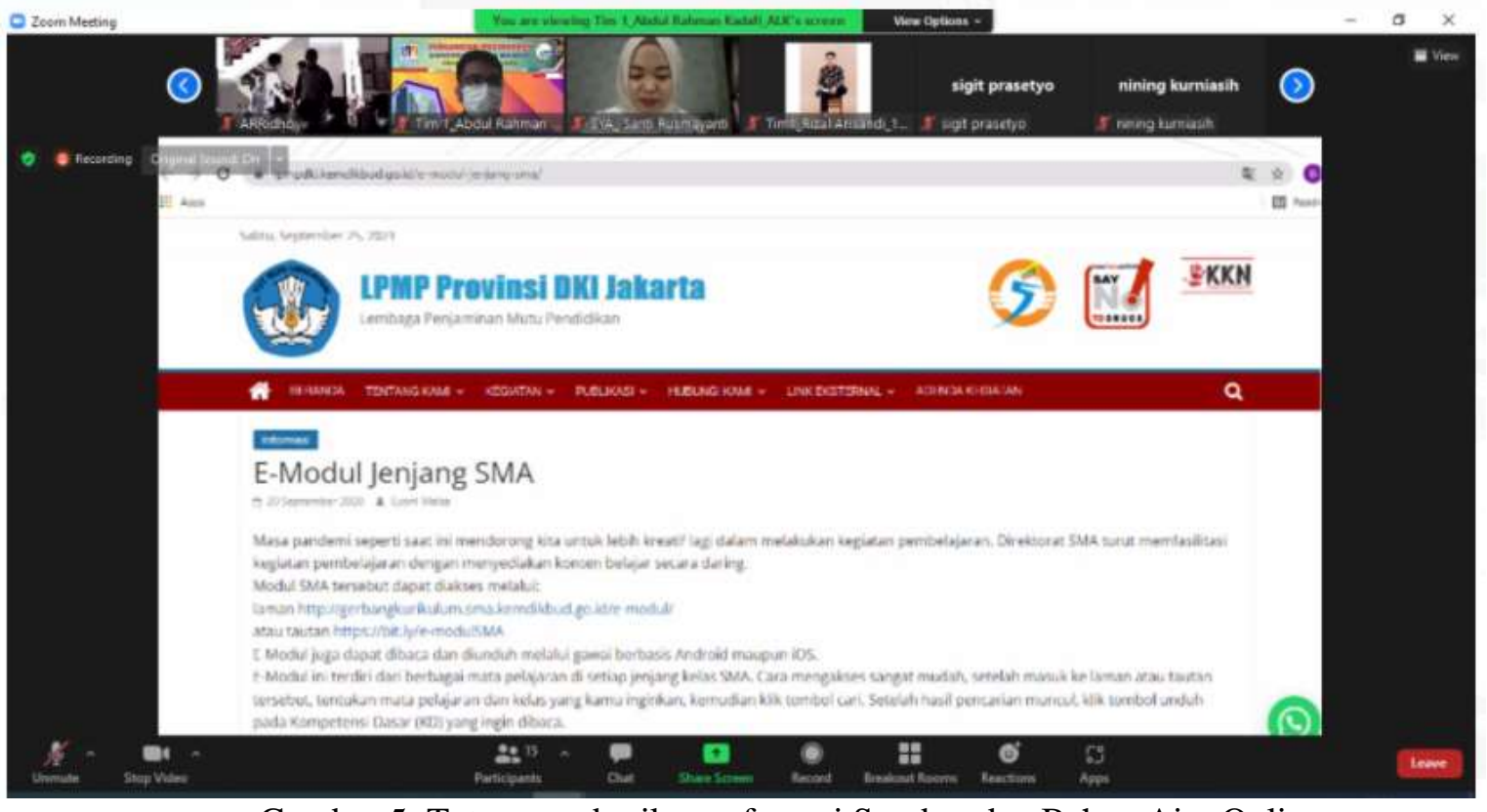

Gambar 5. Tutor memberikan referensi Sumber dan Bahan Ajar Online

Sebelum pelatihan berakhir, panitia memberikan quisioner untuk mengetahui respon tentang pelatihan yang telah dillaksanakan dari para peserta sehingga untuk ke depannya kegiatan pelatihan dapat lebih baik.

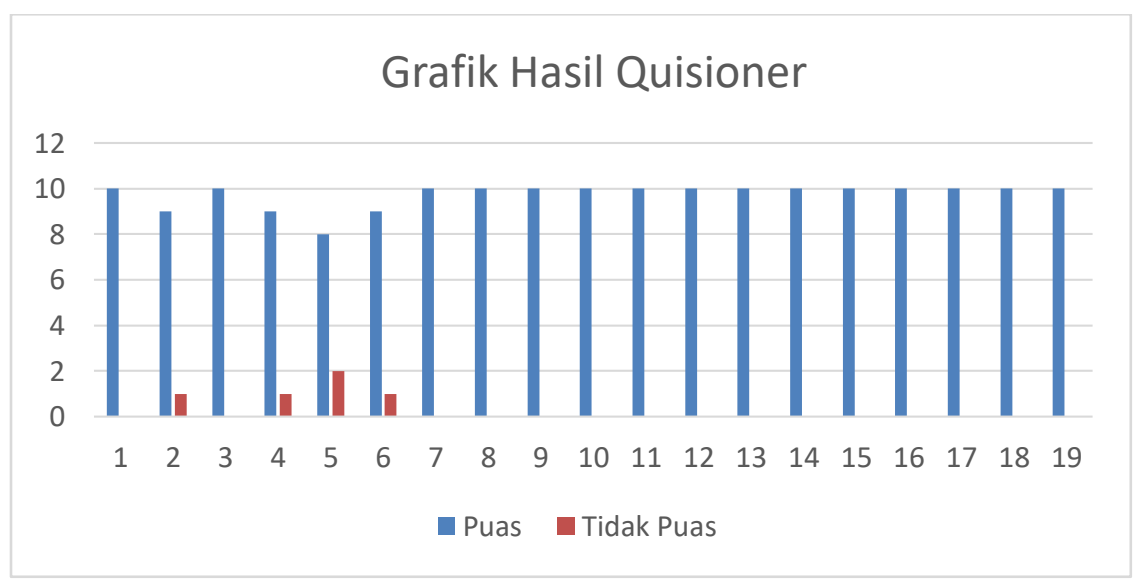

Gambar 6. Grafik Hasil Quisioner

Dari grafik hasil quisioner yang diisi oleh 19 peserta, 15 peserta menyatakan puas pada semua poin quisioner terhadap pelatihan yang diberikan, sementara 4 peserta memberikan penilaian kurang puas pada poin penyampaian pemateri dan poin pelayanan kebutuhan peserta.

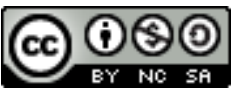

This work is licensed under a Creative Commons Attribution-NonCommercial-ShareAlike 4.0

International License. 
Manfaat yang dirasakan oleh peserta pelatihan yaitu anak-anak yatim piatu dan dhuafa yayasan Yayasan Panti Sosial Ar Ridho Depok menggunakan media online untuk belajar adalah:

1. Dapat mengetahui cara mencari dan mendapatkan media dan bahan ajar online

2. Dapat mengoptimalisasi media dan bahan ajar online dalam meningkatkan pemahaman materi ajar

3. Mengetahui cara dan langkah-langkah untuk mencari dan memanfaatkan media online dalam mendukung pembelajaran

\section{KESIMPULAN}

Kegiatan Pengabdian Masyarakat yang dilakukan oleh Tim dari Fakultas Teknologi Informasi, Jurusan Sistem Informasi Universitas Nusa Mandiri, dalam bentuk Pelatihan Optimalisasi Sumber dan Bahan Ajar Online Sebagai Penunjang Pembelajaran bagi anak asuh Panti Asuhan Ar Ridho telah berjalan dengan Baik sesuai dengan proposal pelaksanaan rencana kegiatan Pengabdian kepada Masyarakat oleh Universitas Nusa Mandiri, serta telah dapat memenuhi target dan hasil keluaran yang dicapai.

Pelaksanaan Pelatihan Optimalisasi Sumber dan Bahan Ajar Online Sebagai Penunjang Pembelajaran bagi anak asuh Panti Asuhan Ar Ridho saat ini dilaksanakan secara online dengan target peserta adalah Anak-anak didik Yayasan Panti Sosial Asuhan Anak Ar Ridho kota Depok dengan menerapkan protocol kesehatan, diharapkan kedepannya kegiatan Pengabdian Masyarakat ini dapat dilaksanakan dengan tatap muka sehingga dapat diberikan manfaat yang jauh lebih banyak lagi

\section{DAFTAR PUSTAKA}

[1] Sadikin A and Hamidah A, 2020 Pembelajaran Daring di Tengah Wabah Covid-19 Biodik 6, 2 p. 109-119.

[2] Anugrahana A, 2020 Hambatan, Solusi dan Harapan: Pembelajaran Daring Selama Masa Pandemi Covid-19 Oleh Guru Sekolah Dasar Sch. J. Pendidik. dan Kebud. 10, 3 p. 282-289.

[3] Witcher B J, 2020 SURAT EDARAN MENTERI PENDIDIKAN DAN KEBUDAYAAN NOMOR 4 TAHUN 2020 p. 1-3.

[4] Basar A M, 2021 Problematika Pembelajaran Jarak Jauh Pada Masa Pandemi Covid-19 Edunesia J. Ilm. Pendidik. 2, 1 p. 208-218.

[5] Siregar L F Pandiangan N- and Sumanik N B, 2021 Kesulitan Belajar Siswa Dalam Pembelajaran Daring Pada Pokok Bahasan Hidrokarbon PENDIPA J. Sci. Educ. 5, 3 p. 412-420.

[6] Assidiqi M H and Sumarni W, 2020 Pemanfaatan Platform Digital di Masa Pandemi Covid-19 Pros. Semin. Nas. ... p. 298-303.

[7] Rahmawati P N and Hasanah E, 2021 Kreativitas dan Inovasi Guru Dalam Pembuatan Materi Guru Pada Masa Pandemi J. Adm. Pendidik. 28, 1 p. 113-124.

This work is licensed under a Creative Commons Attribution-NonCommercial-ShareAlike 4.0

International License. 